\title{
Performance of Broilers Fed Diets With Different Dietary Electrolyte Balance Under Summer Conditions
}

Author(s)

Borgatti $\mathrm{LMO}^{1}$

Albuquerque $\mathrm{R}^{2}$

Meister $\mathrm{NC}^{3}$

Souza $\mathrm{LWO}^{4}$

Lima $\mathrm{FR}^{5}$

Trindade Neto $\mathrm{MA}^{5}$

Graduate student, CENA/ESALQ/USP.

2 Professor at Faculdade de Medicina

Veterinária e Zootecnia (FMVZ),

Universidade de São Paulo.

3 Animal Scientist, MSc Animal Nutrition.

${ }^{4}$ Graduate student, VRA/FMVZ/USP.

5 Professor at Faculdade de Medicina

Veterinária e Zootecnia (FMVZ),

Universidade de São Paulo.

\section{Mail Address}

\section{R. Albuquerque}

Faculdade de Medicina Veterinária e Zootecnia (FMVZ), Universidade de São Paulo.

Av. Duque de Caxias Norte, 225

13.635-900 - Pirassununga, SP.

E-mail: ricalbuq@usp.br

\section{Keywords}

Broiler performance, chloride, electrolytes, potassium, sodium.

\section{ABSTRACT}

The aim of this study was to compare performance and carcass characteristics of broilers fed diets with different Dietary Electrolyte balances (DEB) during the summer season. A total of 1,280 one-day-old Ross sexed chicks were distributed in 32 experimental units according to a randomized block design in a $4 \times 2$ factorial arrangement (4 levels and 2 sexes) and 4 replicates per treatment ( 40 birds per replicate). Feed program consisted of 3 phases (1-21, 22-42, 43-49 days of age). Experimental diets were formulated based on corn and soybean meal and adjusted to $210,250,290$ and $330 \mathrm{mEq} / \mathrm{kg}$ of $\mathrm{Na}+\mathrm{K}-\mathrm{Cl}$ through the addition of sodium carbonate, potassium carbonate and ammonium chloride. Weekly measurements of body weight gain and feed intake were done, and at 49 days, birds were slaughtered to evaluate the dressing percentage and parts yield. Weight gain during the starter phase increased linearly $(p<0.01)$ as DEB increased. Different DEB levels did not affect feed intake or mortality. Carcass characteristics were not affected by treatments. Dietary electrolytic balance influenced weight gain and feed gain ratio from 1 to 21 days, and best results were observed when diets contained 290 and $330 \mathrm{mEq} / \mathrm{kg}$.

\section{INTRODUCTION}

In the last decades, broiler chicken production has experienced a great development. Nevertheless, poultry has also incorporated higher sensibility to stress factors along with this development. Among such factors, heat stress is one of the most important. It is responsible for considerable economic losses such as reduction in body weight gain and high mortality rates, which occur mainly during the summer when environmental temperatures are higher than the comfort temperature for birds.

Several management procedures are performed as an attempt to minimize the deleterious effects of heat stress. Thus, the addition of salts in the feed or drink water can beneficially affect the acid-base equilibrium of animals.

The effect of acid-base balance on the different metabolic processes of animals is currently an issue discussed by researchers worldwide. The concept of Dietary Electrolyte Balance (DEB) has also been applied for different species.

Dietary Electrolyte Balance, according to Mongin (1981), refers to the difference between positive and negative ions present in the diet $\left(\mathrm{Na}^{+}+\mathrm{K}^{+}-\mathrm{Cl}^{-}\right)$and it is commonly expressed as $\mathrm{mEq} / \mathrm{kg}$ of dry matter (DM). Besides the minimum required level of each element, proportions among them must be considered and maintained. The established value that expresses the quantity and relation among them is called Mongin Number (MN) (Silva et al., 1993): 
Borgatti LMO, Albuquerque R, Meister NC, Souza LWO, Lima FR, Trindade Neto MA

\section{$\mathrm{MN}=\mathrm{mEq} \mathrm{Na}{ }^{+}+\mathrm{mEq} \mathrm{K}^{+}-\mathrm{mEq} \mathrm{Cl}$}

This balance is related to the analysis of several factors and specific aspects such as the absorption, storage, utilization and excretion of minerals involved in animal nutrition.

Only a few specific studies in the literature assessed the influence of DEB on the performance and carcass yield of poultry, a fact that makes it difficult to put into practice the ideal balance concept for commercial diets. A previous study reported that values between 200 and $300 \mathrm{mEq} / \mathrm{kg}$ are the optimum DEB for maximum growth in poultry (Mongin \& Sauveur, 1977). On the other hand, extreme values of DEB close to 0 and 600 $\mathrm{mEq} / \mathrm{kg}$ resulted in growth depression. Data published by Johnson \& Karunajeewa (1985) indicated that DEB levels between 250 and $300 \mathrm{mEq} / \mathrm{kg}$ are within the range for maximum growth of broilers.

The aim of this study was to assess different DEB effects on the live performance and carcass yield of broilers raised during the summer in the southeast of Brazil.

\section{MATERIAL AND METHODS}

The assay was carried out from 20/01 to 11/03/2000 at the Avian Experimental Laboratory (Animal Nutrition and Production Department) of Faculdade de Medicina Veterinária e Zootecnia, Universidade de São Paulo (USP).

A total of 1,280 one-day-old sexed Ross broiler chicks were randomly assigned to 32 floor pens, with 40 birds per pen $\left(4.25 \mathrm{~m}^{2}\right)$. The 32 floor pens were grouped into four blocks of eight pens each. The eight treatments were assigned following a $4 \times 2$ factorial arrangement (4 DEB levels and 2 sexes) in a randomized block design. Internal compartments of the building were considered as blocks.

Standard broiler management practices were used. The maximum and minimum temperatures recorded inside the building were $30.6^{\circ} \mathrm{C}$ and $23.8^{\circ} \mathrm{C}$, respectively.

Treatments consisted of different levels of DEB (210, 250,290 and $330 \mathrm{mEq} / \mathrm{kg}$ DM). The levels were obtained by adding different proportions of salts (sodium carbonate, potassium carbonate and ammonium chloride), which were calculated using the following equation:

$$
\mathrm{DEB}=\mathrm{Na}^{+}+\mathrm{K}^{+}-\mathrm{Cl}^{-} \mathrm{mEq} / \mathrm{kg} \mathrm{DM} \text { of diet }
$$

Performance of Broilers Fed Diets With Different Dietary Electrolyte Balance Under Summer Conditions

Diet formulation was performed according to the breed management guide. Experimental corn-soybean based diets were isocaloric and isoproteic, and DEB was adjusted in the different growing phases: starter (1-21 days), grower (22-42 days) and finisher (43-49 days). Diet composition is presented in Table 1 and sodium, chloride and potassium contents of each diet are presented in Table 2.

\begin{tabular}{|c|c|c|c|}
\hline \multirow{2}{*}{ Ingredients (\%) } & \multicolumn{3}{|c|}{ Phases } \\
\hline & Starter & Grower & Finisher \\
\hline Grounded corn & 55.79 & 61.54 & 66.58 \\
\hline Soybean meal 46 & 34.00 & 29.00 & 23.70 \\
\hline DL- Methionine & 0.22 & 0.19 & - \\
\hline L-Lysine & 0.20 & 0.15 & 0.16 \\
\hline Soybean oil & 2.80 & 3.00 & 3.29 \\
\hline Dicalcium phosphate & 1.80 & 1.68 & 1.50 \\
\hline Limestone & 1.08 & 1.20 & 1.12 \\
\hline Vitamin supplement ${ }^{1}$ & 5.00 & 5.00 & 3.00 \\
\hline Mineral supplement ${ }^{1}$ & 0.50 & 0.50 & 0.50 \\
\hline Copper sulphate ${ }^{2}$ & 0.10 & 0.10 & 0.07 \\
\hline Salt supplement ${ }^{3}$ & 3.00 & 3.00 & 3.00 \\
\hline \multicolumn{4}{|c|}{ Calculated analysis } \\
\hline ME (kcal/kg) & 3,08 & 3,150 & 3,220 \\
\hline CP (\%) & 21.00 & 19.00 & 17.00 \\
\hline $\mathrm{Ca}(\%)$ & 1.000 & 1.000 & 0.900 \\
\hline Total P (\%) & 0.673 & 0.636 & 0.589 \\
\hline Available P (\%) & 0.450 & 0.420 & 0.380 \\
\hline \multicolumn{4}{|c|}{ 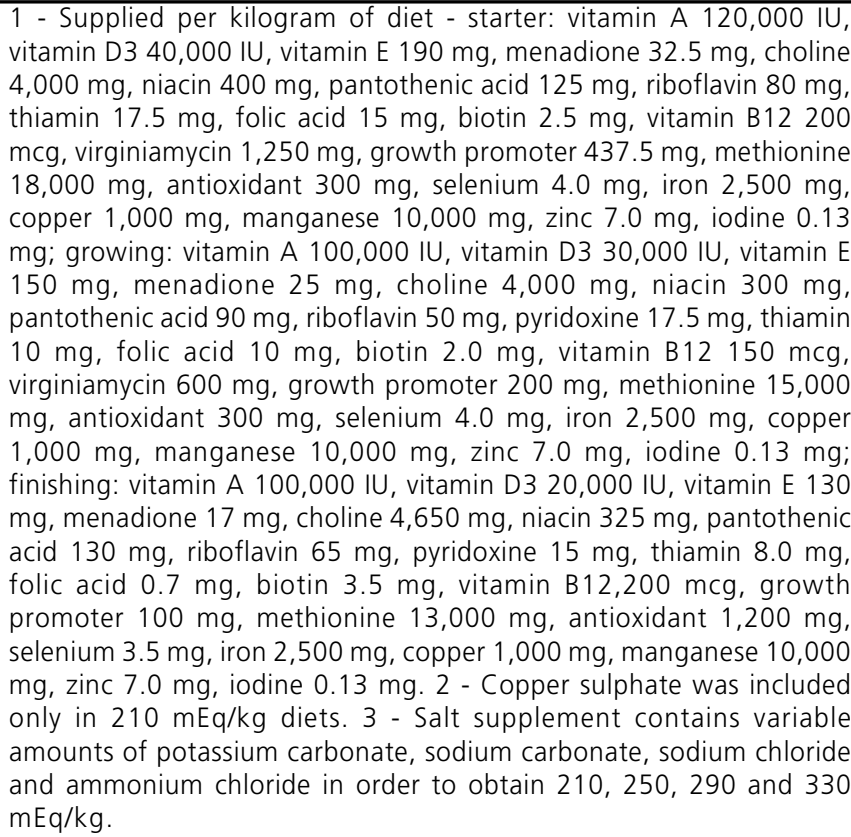 } \\
\hline
\end{tabular}

At 49 days of age, all birds were weighed and killed following technical recommendations and $10 \%$ of the housed birds (four birds/replicate) were used to determine dressing percentage and parts yield. 
Borgatti LMO, Albuquerque R, Meister NC, Souza LWO, Lima FR, Trindade Neto MA
Performance of Broilers Fed Diets With Different Dietary Electrolyte Balance Under Summer Conditions
Abdominal fat content was calculated according to Cabel et al. (1987), including the gizzard surrounding fat. Carcass yield, innards and retail cuts were assessed according to Souza et al. (1994).

Table 2 - Calculated contents of sodium, chloride and potassium in each DEB level of experimental diets.

\begin{tabular}{|c|c|c|c|c|c|}
\hline \multirow{2}{*}{$\begin{array}{l}\text { Period } \\
\text { (days) }\end{array}$} & \multirow[t]{2}{*}{ Nutrients } & \multicolumn{4}{|c|}{ Treatments $(\mathrm{mEq} / \mathrm{kg})$} \\
\hline & & 210 & 250 & 290 & 330 \\
\hline \multirow{3}{*}{ Starter } & Sodium (\%) & 0.18 & 0.18 & 0.18 & 0.18 \\
\hline & Chloride (\%) & 0.39 & 0.32 & 0.27 & 0.22 \\
\hline & Potassium (\%) & 0.95 & 1.02 & 1.12 & 1.22 \\
\hline \multirow{3}{*}{ Grower } & Sodium (\%) & 0.18 & 0.18 & 0.18 & 0.18 \\
\hline & Chloride (\%) & 0.39 & 0.32 & 0.27 & 0.22 \\
\hline & Potassium (\%) & 0.95 & 1.02 & 1.12 & 1.22 \\
\hline \multirow{3}{*}{ Finisher } & Sodium (\%) & 0.18 & 0.18 & 0.18 & 0.18 \\
\hline & Chloride (\%) & 0.39 & 0.32 & 0.27 & 0.22 \\
\hline & Potassium (\%) & 0.95 & 1.02 & 1.12 & 1.22 \\
\hline
\end{tabular}

Performance data were evaluated in the starter, grower and finisher phases and the analyzed characteristics were average body weight gain (BWG, $\mathrm{g} / \mathrm{d})$, average feed intake $(\mathrm{Fl}, \mathrm{g} / \mathrm{d})$, feed to gain ratio (F:G, g feed/g body weight gain) and mortality (\%).

Performance, carcass composition, and mortality data were analyzed by ANOVA as described by Snedecor \& Cochran (1967) using the SAS ${ }^{{ }^{*}}$ General Linear Model procedure.

\section{RESULTS AND DISCUSSION}

Body weight gain (BWG) increased linearly $(p<0.01)$ with DEB from 1 to 21 days of age for both sexes (Table $3)$. The following linear equations were derived $y=$ $29.146938+0.019794 x$ for females and $y=33.081938$ $+0.019794 x$ for males $\left(R^{2}=0.83\right)$. The best BWG was observed at $330 \mathrm{mEq} / \mathrm{kg}$, although the rate of gain decreased with age. Such value is higher than the value considered as ideal $(250 \mathrm{mEg} / \mathrm{kg}$ ) by Mongin (1981), but is within the range of $250-350 \mathrm{mEq} / \mathrm{kg}$ suggested by Johnson \& Karunajeewa (1985). Better performance was also seen in birds from 1 to 21 days old fed with diets containing DEB between 246 and $315 \mathrm{mEq} / \mathrm{kg}$, levels that did not cause tibial dyschondroplasia or acidbase disturbance (Murakami et al., 2000). Borges et al. (1999) reported growing rate depression in chicks between 1 and 7 days old as a result of high values of

SAS Institute Inc., Cary, NC 27511.
DEB in the diet (354-360 mEq/kg) by supplementing $\mathrm{K}^{+}$ or $\mathrm{Na}^{+}$. On the other hand, growing rate depression was not seen in the present study in the group fed the highest DEB level $(330 \mathrm{mEq} / \mathrm{kg})$ by addition of $\mathrm{K}^{+}$ $(1.21 \%)$. On the other experimental phases (22 to 42 , 43 to 49 and 1 to 49 days of age), no differences were observed among treatments for BWG. Results for the period from 1 to 49 days differed from those observed by Borges et al. (1999), who reported better BWG by using diets with $240 \mathrm{mEq} / \mathrm{kg}$, a level similar to the ideal DEB indicated by Mongin (1981).

\begin{tabular}{|c|c|c|c|c|c|}
\hline \multicolumn{2}{|c|}{ Treatment } & \multicolumn{3}{|c|}{ Phase } & \multirow[b]{2}{*}{ Total } \\
\hline Sex & $\overline{\mathrm{DEB}}$ & Starter & Grower & Finisher & \\
\hline \multicolumn{6}{|c|}{ Interactions } \\
\hline \multirow[t]{4}{*}{ M } & 210 & 37.05 & 75.14 & 72.90 & 58.50 \\
\hline & 250 & 38.35 & 75.76 & 54.61 & 56.71 \\
\hline & 290 & 38.85 & 76.17 & 69.50 & 59.23 \\
\hline & 330 & 39.45 & 77.14 & 65.89 & 59.38 \\
\hline \multirow[t]{4}{*}{$\mathrm{F}$} & 210 & 32.83 & 62.95 & 54.79 & 48.88 \\
\hline & 250 & 34.58 & 63.58 & 46.18 & 48.67 \\
\hline & 290 & 35.23 & 63.26 & 59.89 & 50.77 \\
\hline & 330 & 35.32 & 63.06 & 53.93 & 49.90 \\
\hline \multicolumn{6}{|c|}{ Main effects } \\
\hline & 210 & 34.94 & 69.05 & 63.84 & 53.69 \\
\hline & 250 & 36.46 & 69.67 & 50.39 & 52.69 \\
\hline & 290 & 37.04 & 69.71 & 64.70 & 55.00 \\
\hline & 330 & 37.39 & 70.10 & 59.91 & 54.62 \\
\hline M & & 38.43 & 76.05 & 65.72 & 58.45 \\
\hline $\mathrm{F}$ & & 34.49 & 63.21 & 53.70 & 49.54 \\
\hline \multicolumn{6}{|c|}{ Average } \\
\hline Aver & & 36.46 & 69.63 & 59.71 & 54.00 \\
\hline CV ( & & 6.61 & 9.98 & 17.58 & 8.92 \\
\hline \multicolumn{6}{|c|}{ Statistical probability } \\
\hline Line & & 0.0001 & NS & NS & 0.0442 \\
\hline Quac & & NS & NS & NS & NS \\
\hline Devic & & NS & NS & 0.0002 & 0.0202 \\
\hline Sex & & 0.0001 & 0.0001 & 0.0001 & 0.0001 \\
\hline Inter & ons & NS & NS & NS & NS \\
\hline
\end{tabular}

$\mathrm{CV}$ - coefficient of variation. NS - non significant.

As shown in Table 4, no significant ( $p>0.05$ ) differences were observed among treatments for feed intake. However, Oviedo-Rondon et al. (2001) observed feed intake reduction in response to dietary increase of the Mongin number obtained by chloride addition.

Figure 1 shows the quadratic effect of DEB on the $F: G$ ratio of females $(p<0.05)$ in the starting phase, whereas a linear effect was seen for male birds. The estimated optimum F:G ratio is obtained using 266 $\mathrm{mEq} / \mathrm{kg}$. According to Hullan et al. (1987), FG is not 
Borgatti LMO, Albuquerque R, Meister NC, Souza LWO, Lima FR, Trindade Neto MA
Performance of Broilers Fed Diets With Different Dietary Electrolyte Balance Under Summer Conditions altered when DEB is within the range of $155-330 \mathrm{mEq} /$ $\mathrm{kg}$, but nevertheless Borges et al. (1999) observed the same quadratic effect of $\mathrm{K}^{+}$addition that resulted in DEB levels between 119 and $127 \mathrm{mEq} / \mathrm{kg}$ in pre-initial diets.

Table 4 - Daily average feed intake (g/day) for male and female broilers fed with different DEB levels in the starter, grower and finisher phases.

\begin{tabular}{|c|c|c|c|c|c|}
\hline \multicolumn{2}{|c|}{ Treatment } & \multicolumn{3}{|c|}{ Phase } & \multirow[b]{2}{*}{ Total } \\
\hline$\overline{\text { Sex }}$ & $\overline{\mathrm{DEB}}$ & Starter & Grower & Finisher & \\
\hline \multicolumn{6}{|c|}{ Interactions } \\
\hline \multirow[t]{4}{*}{ M } & 210 & 51.48 & 141.64 & 176.93 & 108.04 \\
\hline & 250 & 51.15 & 142.12 & 164.08 & 106.27 \\
\hline & 290 & 51.89 & 145.84 & 173.14 & 109.48 \\
\hline & 330 & 51.61 & 146.21 & 169.35 & 108.97 \\
\hline \multirow[t]{4}{*}{$\mathrm{F}$} & 210 & 48.66 & 124.50 & 145.02 & 94.93 \\
\hline & 250 & 47.76 & 125.35 & 143.99 & 94.76 \\
\hline & 290 & 47.38 & 125.83 & 152.98 & 96.09 \\
\hline & 330 & 47.69 & 126.13 & 149.66 & 95.88 \\
\hline \multicolumn{6}{|c|}{ Main effects } \\
\hline & 210 & 50.07 & 133.07 & 160.97 & 101.48 \\
\hline & 250 & 49.46 & 133.74 & 154.04 & 100.51 \\
\hline & 290 & 46.64 & 135.84 & 163.06 & 102.78 \\
\hline & 330 & 49.65 & 136.17 & 159.51 & 102.42 \\
\hline M & & 51.54 & 143.95 & 170.88 & 108.19 \\
\hline $\mathrm{F}$ & & 47.87 & 125.46 & 147.91 & 95.41 \\
\hline \multicolumn{6}{|c|}{ Average } \\
\hline Aver & & 49.70 & 134.70 & 159.39 & 101.80 \\
\hline$C V($ & & 4.16 & 7.52 & 8.83 & 6.88 \\
\hline \multicolumn{6}{|c|}{ Statistical probability } \\
\hline \multicolumn{2}{|c|}{ Linear } & NS & NS & NS & NS \\
\hline \multicolumn{2}{|c|}{ Quadratic } & NS & NS & NS & NS \\
\hline \multicolumn{2}{|c|}{ Deviation } & NS & NS & 0.0245 & NS \\
\hline \multicolumn{2}{|c|}{ Sex } & 0.0001 & 0.0001 & 0.0001 & 0.0001 \\
\hline \multicolumn{2}{|c|}{ Interactions } & NS & NS & NS & NS \\
\hline
\end{tabular}

CV - coefficient of variation.NS - non significant.

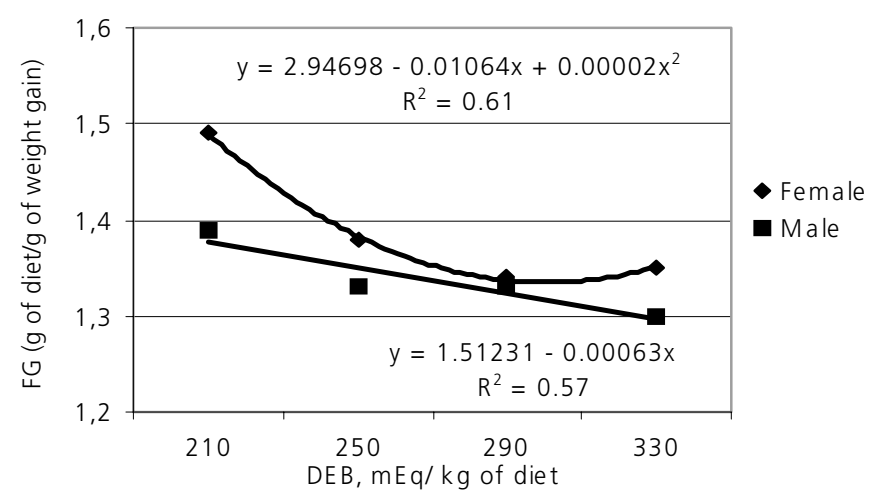

Figure 1 - Effect of different DEB on the feed:gain ratio of male and female broiler chickens from 1 to 21 days old.

The different $\mathrm{Na}+\mathrm{K}-\mathrm{Cl}$ ratios had no effects ( $p>0.05)$ on carcass yield, abdominal fat, heart, liver, gizzard, feet, blood and non-edible innards corroborating results reported by Borges et al. (1999). However, DEB levels in the diets affected some parts yields. A quadratic effect of DEB on wing $(p<0.05)$ is observed in Figure 2 and the best average was obtained by using $210 \mathrm{mEq} / \mathrm{kg}$. The estimated optimum wing yield was seen when levels of 291 and $278 \mathrm{mEg} / \mathrm{kg}$ of diet were used for females and males, respectively. Breast yield increased linearly as demonstrated in the equations $y=0.290070+0.000063 x$ for females and $y=0.268945+0.000063 x$ for males $\left(R^{2}=0.71\right)$, and the best result was observed when $330 \mathrm{mEq} / \mathrm{kg}$ were used. A quadratic effect was observed on leg and thigh yield for males (Figure 3). The estimated optimum leg and thigh yield is achieved by using $286 \mathrm{mEq} / \mathrm{kg}$ of diet.

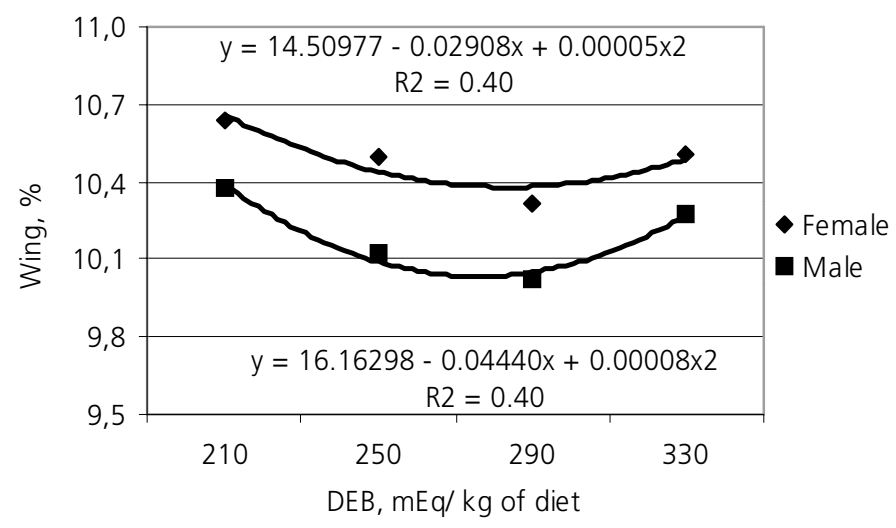

Figure 2 - Effect of different DEB on the wing yield of male and female broiler chickens.

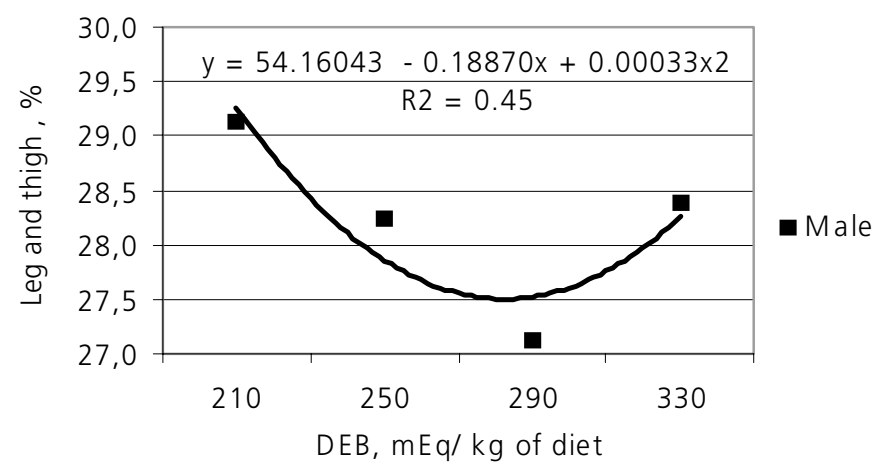

Figure 3 - Effect of different DEB on the leg and thigh yield of male broiler chickens.

Treatment and sex interaction $(p<0.05)$ was observed for back and feather measurements, but there were no quadratic or linear associations $(p>0.05)$ between treatments and the studied characteristics. 
These results are in agreement to Borges et al. (1999) and Johnson \& Karunajeewa (1985), who observed no effects of different DEB on the carcass yield and retail cuts.

The observed percentage of mortality during the entire period was considered low, with an average of $1.86 \%$ and no treatment effect $(p<0.01)$ was observed in any of the evaluated phases, fact that is in accordance to Hullan et al. (1987) and Borges et al. (2000).

Table 5 - Feed:gain ratio for male and female broilers fed with different DEB levels in the starter, grower and finisher phases.

\begin{tabular}{|c|c|c|c|c|c|}
\hline \multicolumn{2}{|c|}{ Treatment } & \multicolumn{3}{|c|}{ Phase } & \multirow[b]{2}{*}{ Total } \\
\hline$\overline{\text { Sex }}$ & $\overline{D E B}$ & Starter & Grower & Finisher & \\
\hline \multicolumn{6}{|c|}{ Interactions } \\
\hline \multirow[t]{4}{*}{ M } & 210 & 1.39 & 1.88 & 2.43 & 1.85 \\
\hline & 250 & 1.37 & 1.87 & 3.04 & 1.87 \\
\hline & 290 & 1.33 & 1.91 & 2.52 & 1.85 \\
\hline & 330 & 1.31 & 1.90 & 2.58 & 1.83 \\
\hline \multirow[t]{4}{*}{$\mathrm{F}$} & 210 & 1.49 & 1.98 & 2.64 & 1.94 \\
\hline & 250 & 1.38 & 1.97 & 3.24 & 1.95 \\
\hline & 290 & 1.34 & 1.99 & 2.59 & 1.89 \\
\hline & 330 & 1.35 & 2.00 & 2.78 & 1.92 \\
\hline \multicolumn{6}{|c|}{ Main effects } \\
\hline & 210 & 1.44 & 1.93 & 2.54 & 1.89 \\
\hline & 250 & 1.36 & 1.92 & 3.14 & 1.91 \\
\hline & 290 & 1.34 & 1.95 & 2.56 & 1.87 \\
\hline & 330 & 1.33 & 1.95 & 2.68 & 1.88 \\
\hline M & & 1.34 & 1.89 & 2.64 & 1.85 \\
\hline $\mathrm{F}$ & & 1.39 & 1.99 & 2.81 & 1.92 \\
\hline \multicolumn{6}{|c|}{ Average } \\
\hline Aver & & 1.37 & 1.94 & 2.73 & 1.89 \\
\hline CV ( & & 4.73 & 3.45 & 15.56 & 2.87 \\
\hline \multicolumn{6}{|c|}{ Statistical probability } \\
\hline \multicolumn{6}{|c|}{ 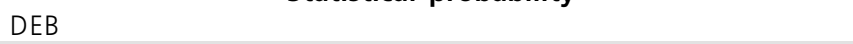 } \\
\hline Line & & 0.0001 & NS & NS & NS \\
\hline Qua & & 0.0278 & NS & NS & NS \\
\hline Devi & & NS & NS & 0.0002 & NS \\
\hline Sex & & 0.002 & 0.0001 & 0.0001 & 0.0001 \\
\hline Inter & ions & NS & NS & NS & NS \\
\hline \multicolumn{6}{|c|}{$\begin{array}{l}\text { CV - coefficient of variation.NS - non significant. 1 - Graduate } \\
\text { student, CENA/ESALQ/USP. } 2 \text { - Professor at Faculdade de Medicina } \\
\text { Veterinária e Zootecnia (FMVZ), Universidade de São Paulo. } 3 \text { - } \\
\text { Animal Scientist, MSC Animal Nutrition. } 4 \text { - Graduate student, VRA/ } \\
\text { FMVZ/USP. } 5 \text { - Professor at Faculdade de Medicina Veterinária e } \\
\text { Zootecnia (FMVZ), Universidade de São Paulo. }\end{array}$} \\
\hline
\end{tabular}

\section{CONCLUSIONS}

The observed results suggest that DEB for broilers under summer conditions affects bird performance in the starting phase (1-21 days of age) with the best results for BWG and $F G$ obtained at $330 \mathrm{mEq} / \mathrm{kg}$. However, the influence of DEB on performance and carcass yield parameters must be better examined because available data are divergent in the establishment of the ideal electrolytic balance.

\section{REFERENCES}

Borges SA, Ariki J, Moraes VMB, Silva AVF, Maiorka A, Sorbara JOB. Relação $(\mathrm{Na}+\mathrm{K}-\mathrm{Cl})$ em dietas de frangos de corte durante o verão. In: Conferência Apinco de Ciência e Tecnologia Avícolas; 1999; Campinas, São Paulo. Brasil. p.20.

Borges SA, Ariki J, da Silva AVF, Maiorka A, Laurentiz AC. Balanço eletrolítico na dieta pré-inicial de frangos de corte. Revista Brasileira de Ciência Avícola 2000; (Suplemento 2):38.

Cabel MC, Goodwin TL, Waldroup PW. Reduction in abdominal fat content of broiler chickens by the addition of feather meal to finisher diets. Poultry Science 1987; 66:1644-51.

Hullan HW, Simons PCM, Schagen PJW, Mcrae KB, Proudfoot FG. Effect of dietary cation-anion balance and calcium content on general performance and incidence of leg abnormalities of broiler chickens. Canadian Journal of Animal Science; 1987 67:165-77.

Jonhson RJ, Karunajeewa $\mathrm{H}$. The effects of dietary minerals and electrolytes on the growth and physiology of the young chick. Journal of Nutrition 1985; 115:1680-1690.

Mongin P. Recent advances in dietary anion-cation balance: applications in poultry. Proceedings of Nutrition Society 1981; 40(3):285-294.

Mongin P, Sauveur B. Interrelationships between mineral nutrition, acid-base balance, growth and cartilage abnormalities. In: Boornman, KN, Wilson, BJ (Ed.). Growth and poultry meat production. Edinburgh(UK): British Poultry Science; 1977. p.23547.

Murakami AE, Galli JR, Martins EN, Volski T, Furlan AC, Pereira MS. Efeito do balanço eletrolítico em dietas de baixo conteúdo de proteína no desempenho e na incidência de discondroplasia tibial em frangos de corte. Revista Brasileira de Ciência Avícola 2000; (Suplemento 2):40.

Oviedo-Rondon EO, Murakami AE, Furlan AC, Moreira I, Macari M. Sodium and Chloride requirements of young broiler chickens fed corn-soybean diets (one to twenty-one days of age). Poultry Science 2001; 80:592-598.

Silva AVF, Freire WJ, Satto J. Estudo de diferentes indicadores do estresse calórico em frangos de corte. Revista do Setor de Ciências Agrárias 1993; 12:88-90.

Snedecor GW, Cochran BWG. Statistical methods. 2 ed. Ames(IA): lowa State University Press; 1967.

Souza PA, Souza HBA, Campos FP, Brognoni E. Desempenho e características de carcaça de diferentes linhagens comerciais de frangos de corte. Revista da Sociedade Brasileira de Zootecnia; 1994 23(5):782-91. 